\title{
The Contemporary Pertinence of the Later Foucault. Have his Strategies of Resistance Stood the Test of Time?
}

\author{
Benda Hofmeyr \\ Department of Philosophy \\ University of Pretoria, Pretoria \\ South Africa, 0002. \\ Department of Philosophical Anthropology \\ Faculty of Philosophy \\ Radboud University Nijmegen \\ P. O. Box 9103, $6500 \mathrm{HD}$ \\ Nijmegen, The Netherlands. \\ benda.hofmeyr@up.ac.za or b.hofmeyr@phil.ru.nl
}

\begin{abstract}
What happened during the fairly long silence following The History of Sexuality? ... had he [Foucault] not trapped himself within the concept of power relations?' asks Deleuze. According to him, Foucault would have answered 'that power does not take life as its objective without revealing or giving rise to a life that resists power' (Deleuze 1988: 94). The object of this essay is to assess what happens 'if the transversal relations of resistance continue to become restratified'. When the long silence was finally broken, Foucault proposed a more affirmative - aesthetic - mode of countering power, but what exactly is the contemporary pertinence of the late Foucault's insistence that an aesthetics of existence provides us with the means to resist an over-determination by power. This essay follows the trajectory of Foucault's turn to aesthetics: from care of the self as a reaction against constraining governmental regulations and institutionalised normalisations; to self-(trans)formation as a more affirmative strategy; to the present day in which cultural capitalism has usurped all aesthetic strategies of resistance. The essay therefore questions the potentially subversive status of self-creation in the light of the fact that contemporary governmental rationalities encourage self-stylising individuality, alternative life-style choices and original ways of being different. It concludes by arguing in favour of its continued relevance.
\end{abstract}

\section{The Problematics}

Many critics thought that Foucault's work of the 1970s overstated the extent to which individuals could be subjected to the influence of normalising power, leaving them little room to resist. The later, more optimistic Foucault reinvested the individual with the capacity to resist over-determination by power through the Greco-Roman notion of 'care of the self', i.e. practices and techniques that entail a stylisation of self, an aesthetics of existence. Today, however, the question at hand is whether this form of re- 
sistance has itself not been inscribed into the workings of normalising power? For it would seem as if contemporary governmental rationalities encourage self-stylising individuality, alternative life-style choices and original ways of being different. In short, alterity itself has come to be the other to resistance.

Present-day Dutch society is exemplary in this regard. In 2001, for example, Atelier Van Lieshout (AVL), founded by the Dutch artist Joep van Lieshout, realised AVL-Ville, an experimental 'free state' in the port of Rotterdam - an own private enclave aestheticised down to its every socio-economic fibre. ${ }^{1}$ It was 'marketed' as an agreeable mix of art environment and sanctuary, with the special attraction that everything is fully operational. Not art to simply look at, but to live with, to live in and to live by - constituting what appeared to be an original response to Foucault's question why everybody's life cannot become a work of art, relating art not only to objects, but to life (Foucault 1983c: 350). With an own constitution, currency, transport and flag, AVL-Ville supposedly tried to provoke the established order and to spur public discussion about alternative forms of community. In a country where everything is becoming increasingly regulated, according to Joep van Lieshout, he wanted to create a self-contained islet where almost anything is still possible. However, as a governmentally sanctioned - if not subsidised - settlement, its subversive potential turned out to be quite questionable. Apart from functioning as an official part of Rotterdam Cultural Capital of Europe 2001, its so-called 'independently drafted' constitution coincided almost seamlessly with the Dutch system of $2001 .^{2}$ 'Even there where freedom seems to reign supreme, the irrepressible need for control seeps in' - was how one of the Dutch websites phrased it. ${ }^{3}$ Instead of countering subjugation, Atelier Van Lieshout's efforts to challenge and recreate our existing subject identities differently succeeded only in facilitating more effective governance and docility. ${ }^{4}$

How then can an aesthetics of existence still be subversive if power itself is responsible for the wholesale 'aestheticisation' of society? ${ }^{5}$ In other words, are the possibilities for resistance that emerge from the later Foucault's work resilient enough to remain relevant even now? This is the question that the present essay seeks to address. The critical reader might balk at this line of questioning. By transposing the present problems of cultural capitalism onto Foucault's preoccupation with the Ancients, with a past that can precisely be interpreted as counter-cultural, do we not thereby suppose a misguided sense of the political relevance of Foucault's work? Ancient culture can certainly be interpreted as a way of life and set of attitudes opposed to or at least at variance with the prevailing social norms. The classical age is pivotal to all Foucault's writings. According to him,

'[i]t's a good thing to have nostalgia toward some periods on the condition that it's a way to have a thoughtful and positive relation to your own present' (Foucault 1982b: 12).

1 The Dutch artists' collective, Atelier Van Lieshout (AVL) consists of approximately thirty members. They gather their artistic and technical expertise to create individual pieces, which in turn can be put together to create organised forms of communal working and living that circumvent conventional categories (see www.ateliervanlieshout.com).

2 Apart from negligible deviations on the formation of sects and polygamy.

3 See http://www.classic.archined.nl/news/0106/avl-ville.html (my translation).

4 For a more exhaustive critique of AVL's work from a Foucaultian perspective, see my article (Hofmeyr 2005).

5 In this regard, see for example Eagleton 1990. 
Throughout his life, Foucault continually turned to the past, to other historical periods (epistemes) to indicate that our present way of acting and thinking is not the only possibility. The question has always been whether or not Foucault's genealogies succeed in revitalising the present and uncover other possible ways of being. Can Foucault's genealogy of ethics and the concomitant practices or technologies regarding oneself relate the ancient world in a way that questions the complacency of the present in a meaningful way? Or to restate our original question: are the possibilities for resistance that emerge from the later Foucault's preoccupation with the Ancients resilient enough to remain relevant even now?

In an attempt to answer this question, I shall first consider the evolution that resistance has undergone - from reaction to creation through to normalisation - in Foucault's later works, starting with the first volume of his Histoire de la sexualité, published in 1976. I shall then use Foucault's conception of critique and his reading of the Deleuzian notion of difference and repetition to show how and to what extent care of the self is still capable of subverting the 'government of individualisation' (Foucault 1982a: 129) through the invention of new forms of self-government.

\section{The Evolution of Resistance in the Later Foucault: Reaction-Creation-Normalisation}

In Foucault's later work, resistance undergoes a certain evolution. ${ }^{6}$ In the Method section of Volume I of The History of Sexuality (1976), Foucault understands resistance as tactical reversal (HS I, 156/207), that is, resistance can be pinpointed where local clashes are assimilated or re-inscribed into the existing order. This re-appropriation entails a mutual conditioning in which both active and reactive force are strategically altered. In other words, although power bears the inherent threat of domination, the threat is countered by the constitutive potential of reversal, i.e. the possibility of overturning subjugating relations of force. Despite this possibility afforded by reversal, it confines resistance to a reactive stance - to the ability to seize the power to react-to constraining governmental regulations, institutionalised normalisations and societal intolerance. Judith Butler's notion of 'gender performativity', which she introduced in her 1990 book, Gender Trouble, affords a good example of this form of resistance. She challenges the sex/gender (nature/culture) distinction and claims that sex is always already gendered. 'Sex' is the rubric under which reproductive functions, desire, pleasure, etc. become unified within a masculinist economy that naturalises heterosexuality. In Butler's own words, 'Gender is a matter of doing and effects rather than an inherent attribute, an intrinsic feature.' If gender is indeed performative, then one could potentially 'perform' one's gender differently and thereby disrupt heteronormativity. This disruption could then lead to the democratisation of the field of gender norms. However, the question is whether the overly exaggerated feminised gestures of the effeminate man effectively subvert the sex-gender equation or merely reinforces it by re-enacting stereotypical feminine mannerisms?

The obvious question that emerges in this context is, if resistance is a mere re-action or negation, what is inherently creative about it? How can the power of resistance be

6 I am indebted to other Foucault scholars who have already outlined the first two stages of this evolution See specifically John Hartmann's paper presented at the 3rd Annual Meeting of the Foucault Circle, 'Power and Resistance in the Later Foucault' on the Internet [mypage.siu.edu/hartmajr/pdf/jh fouccirc_03.pdf]; and Thompson, K. (2003). 'Forms of Resistance: Foucault on Tactical Reversal and Self-Formation", in Continental Philosophy Review 36(2), 113-138. 
understood as a positive action on its own terms? Foucault scholars have come up with numerous theories in an attempt to explain what happened during the eight year gap separating the publication of Volume I in 1976 and the subsequent second and third volumes of Foucault's Histoire in 1984. There is certainly evidence of a shift of emphasis regarding power and resistance, if not a fundamental rethinking of the analysis of power and knowledge. James Miller's influential, if somewhat sensationalist, biography of Foucault ${ }^{7}$ offer one of the foremost interpretations of this lull in Foucault's otherwise prolific career. According to Miller, the turn towards governmentality and the technologies of the self can be understood as an implicit concession on Foucault's part, an admission that his depiction of power and resistance in Volume I was too constrictive. ${ }^{8}$ There is certainly a readily discernible modification in Foucault's consideration of power and resistance in this period, culminating in his 1982 essay, 'The subject and power'. Here, and in the subsequent second and third volumes of his History of Sexuality, a reconceptualised self appears on the scene: the self is now no longer considered as the passive product of an external system of constraint and prescription, but as the active agent of its own formation. Foucault consequently articulates a more positive means of resistance, that is, resistance as autonomy through heteronomy. The break separating the publication of the first and later two volumes should nevertheless not be understood as clean-cut, as if the earlier and later notions of resistance would be incommensurable. In fact, in a 1984 interview entitled 'The Ethic of Care for the Self as a Practice of Freedom' (Foucault 1984), it becomes apparent that resistance as creative force cannot do away with the necessity of resistance as reactive force. ${ }^{9}$ Here Foucault introduces the self in a Greek guise, i.e. as individual agency characterised by autarky and auto-affection. It is set in opposition to all those material, historical, economic, discursive and linguistic structures, practices and drives that subject the subject while constituting it through subjectivisation. Not that the subject is ever entirely 'outside' of power. According to Foucault, the subject's embeddedness in power precisely 'does not entail the necessity of accepting an inescapable form of domination' (Foucault 1977: 141, my emphasis). Rather, it musters autonomy despite of but also through heteronomous power relations. The disempowering forces, which it resists, are simultaneously the forces that power self-creation. For as Greenblatt (1980) argues, the freedom of the arts of self does not consist in self-creation itself, but in the experience of self-formation in the face of all the other forces that fashion us. ${ }^{10}$

Foucault's conception of power therefore leads to the conclusion that, as Balibar (2002: 15) puts it, 'the conditions of existence which are to be transformed are woven

7 See, for example, Miller's sensationalist account of Foucault's commitment to pleasure as a form of resistance ( $c f$. Miller 1993: 278).

8 Miller portrays the period of Foucault's 1977-78 Collège de France lectures as 'a time of crisis for him'. In his 1978 lectures, Foucault turned abruptly to a new topic - what he came to call 'governmentality'. 'There is nevertheless a certain irony about this work in these months. Despite the deployment of fresh historical evidence and the marshalling of a new battery of concepts, the disposition of forces described... is essentially the same as that described in ...Discipline and Punish. His approach changed but he still didn't know where he was going' (cf. Miller 1993: 298-301).

9 The perceptive reader will note that throughout this paper I refer to essays and interviews conducted or published before The History of Sexuality was conceived - references which serve to support the continuity of Foucault's thinking.

10 Foucault (HS II, 11/17) cites Greenblatt (1980) as one of the few studies of aesthetics of existence done since Burckhardt (1935). Burckhardt (p. 160) discusses fame being achieved in the Renaissance by courtiers who made their lives models of moderation and harmony. Foucault sees in this an example of 'the hero as his own work of art' (1983c: 370). Cf. Simons 1995: 76. 
from the same cloth as the practice of transformation itself' - they are both of the order of 'an action upon an action' (Foucault 1982a: 221). The power relation is indeed constituent, whereas the more or less stabilised social norms, the norms of behaviour, are constituted. As a consequence, liberty might just be within our reach, but never quite attainable. ${ }^{11}$ Power in Foucault is two-faced Janus incarnate, the middle ground between liberation and subjugation, both the beginning and the end of freedom. The self can resist power because it is enmeshed in power - in the very thing that makes resistance necessary. However, every act of resistance instates new relationships of power that in turn have to be resisted (Foucault 1984: 4). As a result, the self faces the danger of being caught in an infinite regress (Balibar 2002: 19) ${ }^{12}$ or return of liberation and domination, of self-invention and self-refusal. The trajectory leading from resistance to liberation, from liberation to domination, and back again (via resistance) has come to be inscribed in the very texture of the individual.

Accordingly, to avoid normalisation, every new formation of resistance dismantles itself in an effort to resist more effectively. In other words, every newly created subject identity is abandoned before it can be incorporated in the prevailing regime. The powers that be consequently no longer have to face one formidable force of resistance, but countless small individual acts of self-(re)formation. Moreover, it would appear that the prevailing order has succeeded in defusing whatever subversive potential they might have by organising itself around these relays. One might even say that Foucault's question, 'why everyone's life can't be turned into a work of art?' (1983c: 350) has become the motto of our present capitalist universe. The official website of Barbie Inc., for example, urges today's children 'to use art and creativity as a means of self-expression' - cultivating small Foucaultians from the get-go, as it were. Not even popular artistic expressions, like Joep van Lieshout's 'free state' - posing as a critical alternative to the established order - succeed in being more subversive than consumerist trends such as those exemplified by Barbie Inc. Instead of constituting a more effective provocation of inhibiting governmental rationalities, these forms of self-expression turn out to be state sanctioned - their seditious potential is sublimated through incorporation in schemes orchestrated by precisely those powers they seek to contest. In other words, instead of effectively promoting new forms of subjectivity through the refusal of the kind of subjectivity coupled to the state and imposed on us for several centuries, as Foucault (1982a: 216) urges, Barbie Inc. and Van Lieshout's self-transformative labours are forging exactly the kind of malleable individuality susceptible to subjugation. For the latest governing techniques posit 'intelligent' limits limits sensitive to our every dandyish whim, which means that being 'different' has itself become part and parcel of subjugation. Now, before we conclude that Foucault's notion of an aesthetics of existence has passed its sell-by date, we should consider his

11 According to Eagleton (1990: 387), Foucault is exemplary of what he calls 'libertarian pessimism'. The oxymoron is instructive, Eagleton continues. Foucault's position is libertarian therein that it advocates an aesthetics of existence, i.e., 'an existence blessedly free from the shackles of truth, meaning and sociality'. At the same time, however, it is pessimistic, 'because whatever blocks such creativity - law, meaning, power, closure - is acknowledged to be built into it, in a sceptical recognition of the imbrication of authority and desire'. Charles Taylor (1984) points out that although Foucault wishes to discredit the very notion of a liberation from power, his own concept of power does not in fact make sense without the idea of such liberation.

12 'Regress' is here used in the philosophical sense of the term. In other words, it refers to a series of actions (practices or technologies of the self) in which resistance is continually reapplied to its own result without approaching a useful conclusion. 
understanding of the critical attitude as virtue, which he defended in a lecture given in 1978 to the French Society of Philosophy, entitled 'What is critique?'13

\section{Critique as Virtue}

Critique, according to Foucault, 'only exists in relation to something other than itself' (Foucault 1978: 25). It is a certain way of relating to existing reality, to knowledge, action, society, culture, and also to others, that despite this dependency and heteronomy remains 'other'. In other words, as critique it only exists in as much as it resists being assimilated into its object. As 'a means for a future or a truth that it will not know nor happen to be' (ibid.), it is aimed at exposing the limits of its object and this exposure of the limit, in turn, is associated with the practice of virtue - as if virtue is to be found in the very opposition to the established 'order of things'.

Virtue, as the conceptual opposite of vice, is generally understood as a character trait valued as being good - a quality that conditions and characterises a certain kind of action or practice. It is associated with an ethics that resists blind subjection to objectively formulated moral codes. True to its Latin root virtus, it should be conceived in terms of force or strength, the strength not to merely submit to but to critically engage with those norms. In L'usage des plaisirs, Foucault explains that classical moral reflection addressed men concerning precisely those conducts in which they were called upon to exercise their rights, their power, their authority, and their liberty. The moral demands made on men did not inhibit their conduct by way of prohibitions, but incited them to exercise and affirm their privilege, potential and autonomy. The themes of austerity did not express essential interdictions, but should be understood as the elaboration and stylisation of an activity in the exercise of its power and the practice of its liberty (HS II, 23/30). For Foucault, then, this critical relation takes shape as 'a specific stylization of morality' (Butler 2000: 217). ${ }^{14}$

Critique, as we have seen, is not something that can be defined independently of the various objects by which it itself is defined. In this lecture, Foucault precisely situates it in terms of government: 'how not to be governed' (Foucault 1978: 28). Herewith he is not proposing the transcendence of all imposed limits, i.e. opting for anarchy or asking how to become wholly ungovernable. He is not therefore simply returning to his earlier notion of 'tactical reversal', of resistance understood as negation or opposition. It is a specific question that emerges in relation to a specific form of government:

'how not to be governed like that, by that, in the name of those principles, with such and such an objective in mind and by means of such procedure, not like that, not for that, not by them' (ibid). ${ }^{15}$

Accordingly, critique consists in challenging the demand for complete compliance by subjecting every governmental obligation imposed on individuals to a rational and reflective assessment. We have to face these imposed principles head on, not in a gesture of rejection, but as an act of defiance that challenges and displaces them in order to de-

13 'What is critique?' is published in The Politics of Truth, a compilation of lectures given by Foucault on various occasions from 1978 to 1984, in which he explicitly deals with the answer Kant gave to the question, 'Was ist Aufklärung?' in the German newspaper Berlinische Monatschrifte in 1784, exactly two hundred years before Foucault's death.

14 Judith Butler's essay, 'What is critique? An essay on Foucault's virtue', referred to here was originally delivered, in shorter form, as the Raymond Williams Lecture at Cambridge University in May 2000. In this essay, she moves (with Foucault) beyond resistance understood as tactical reversal.

15 In Hegelian terms, this would be a determinate negation, as opposed to a mere re-action to or indeterminate negation of governing forces. 
velop the arts of governing (Foucault 1978: 28-29). Moreover, to be distrustful of governmentally imposed absolutes, in the way Foucault intended, implies a critical practice that fundamentally transforms us in the process (HS II, 10-11/16-17). ${ }^{16}$ As Butler (2000: 218) explains:

'Such lives do not simply conform to moral precepts or norms in such a way that selves, considered pre-formed or ready-made, fit themselves into a mold that is set forth by the precept. On the contrary, the self fashions itself in terms of the norm, comes to inhabit or incorporate the norm, but the norm is not in this sense external to the principle by which the self is formed'.

What Foucault terms 'the politics of truth' (1978: 32) pertains to those structures of power that predetermine what will and will not count as truth, that delineate a given field of knowledge, and that consequently organise the world in a certain controlled and controllable fashion. Critique takes effect as soon as the subject gives herself the right to question the politics of truth, as soon as the individual starts challenging the confines of his/her power/knowledge determined world. According to Foucault (1978: 32), this activity of questioning pre-established subject identities and trajectories will be 'the art of voluntary insubordination, that of reflected intractability' that would 'insure the desubjugation of the subject'.

In this context, 'critique means putting forth universal and indefeasible rights' (ibid., p. 30). The emphasis thus shifts away from prohibitions to rights, away from subjection to freedom. However, it does not put these rights forth as positive rights. By 'putting forth' these rights, one is claiming the flexibility and manoeuvrability of identity and action to which one is entitled. It is the act of recuperating agency that necessarily challenges pre-given power/knowledge structures. It is the positing of limitation itself, the positing of the 'right' to limit imposed force relations. In Foucault's words, "" $[t]$ o not want to be governed" is ... not accepting as true ... what an authority tells you is true, or at least not accepting it because an authority tells you that it is true, but rather accepting it only if one considers valid the reasons for doing so' (ibid., p. 31).

Here it is important to realise that the reasons provided always operate on two registers. If the government tells you to 'transform yourself', the official reasons might not be objectionable at all. Why not create your life as a work of art, as Joep van Lieshout did, if you can thereby fully actualise your potential, which, in the end, will cultivate a strong community supported by unique individuals? At the same time, however, one should never lose sight of the hidden agenda or underlying order, which supports a certain governmental imperative - the politics of truth, in other words. Self-transformation might be encouraged not because the state has any vested interest in the uniqueness of its citizens, but rather in their docility. Individuals will then be urged to express their artistic and anarchistic desires within the governmentally regulated framework provided so that these desires can be sublimated and channelled towards the greater good. ${ }^{17}$

We nevertheless find ourselves in murky waters, for what, as Butler points out, will constitute a ground of validity for accepting authority? If accepting authority merely

16 Foucault's notion of an aesthetics of existence entails 'those actions by which men not only seek themselves rules of conduct, but also seek to transform themselves in their singular being' (HS II, 10-11/16-17).

17 By extension, this means that even compliance to governmental regulations can be subversive, as long as it remains critically aware of the 'politics of truth' supporting the reasons given. 
depends on consent, Foucault's position risks being reduced to a form of voluntarism. However, the critical practice does not stem from innate human freedom, but is formed instead in the crucible of a particular exchange between a set of rules or precepts (which are already there) and a stylisation of acts (which extends and reformulates that prior set of rules and precepts)' (Butler 2000: 222).

So when Foucault talks about self-stylisation, he is referring to a certain ethical labour (travail éthique), which the self performs on itself in relation to the rules and values that $\mathrm{s} / \mathrm{he}$ is supposed to adhere to (HS II, 27/34). However, morality must be defined, not by the conformity of the action with the code, but in reference to the intention and the freedom of the subject, and thus, ultimately, to the way in which the will determines itself. ${ }^{18}$ '[F]or what', asks Foucault (1984: 4), 'is morality, if not the practice of liberty, the deliberate practice of liberty?' 19 The practice of freedom is therefore not synonymous with respect for the law. In the second and third volumes of his History, Foucault repeatedly stresses that the Greeks had very few codes and prohibitions. Strict adherence to these was never an object of great moral concern. What was important was the necessity of the subject determining and expressing not only his will, but also his way of being through action. ${ }^{20}$ Foucault therefore implicitly takes up the traditional distinction between act-centred morality and agent-centred ethics. Instead of understanding virtuous action by referring it to a set of pre-established prescriptions, he places the emphasis on the agent. He thereby attaches little importance to 'duty' and defines virtue itself from the conduct that a virtuous man adopts (Han 2002: 159). ${ }^{21}$ How I ought to act then also becomes a matter of how I choose to act - whether I choose to conform to or diverge from the code (HS II, 26/33). It is a choice that cannot be reduced to voluntarism, for it reflects an entire mode of being.

Foucaultian self-stylisation then refers to forms of moral subjectivisation; that is, the way in which we constitute ourselves as moral subjects of our own actions. And if moral subjectivisation is always directly tied to the moral code, self-stylisation will

18 Thus, in clear opposition to the subject's subjection to the law, characteristic of the Judeo-Christian understanding of morality, Foucault advocates an ethics that can be defined from the 'conduct' of the individual - the way in which he gives 'deliberate form' to his liberty (Foucault 1984a: 4). Self-transformation is therefore concerned with the way in which one ought to 'conduct oneself' - 'that is, the manner in which one ought to form oneself as an ethical subject acting in reference to the prescriptive elements that make up the code' (HS II, 26/33). Given the code of conduct and various ways in which individuals conduct themselves, which can be defined by their degree of conformity with or divergence from the code, there are different ways to 'conduct oneself' morally.

19 Foucault shares with Kant the idea that moral behaviour presupposes a rational conception of action (the 'reflective form', the 'reflective practice'), which leaves any action determined by sensible inclination outside the moral field. However, the difference between Foucault and Kant lies in their respective conceptions of the 'practice of freedom'. For Kant, it is respect for the law alone that allows us to decide the morality of an action. See Kant (1785: 55): '[A]n action from duty has its moral worth not in the purpose to be attained by it but in the maxim in accordance with which it is decided upon... duty is the necessity of an action from respect for law'.

20 Kant's transcendental approach clearly excludes the necessity and even the possibility of taking into account the agent's mode of being, which can only be defined empirically and a posteriori. Foucault thus diverges from Kant by stressing that the Greeks would not have defined morality independently of the quality of the moral agent, and would not have defined this quality independently of his actions. It is not intention alone that decides the moral value of an action. Intention cannot be examined on its own without taking the mode of being of the agent into account. This is not definable a priori, but is the result of the constitution of the subject by itself (Han 2002: 159).

21 In this regard, Han refers to Annas, J. (1981). An Introduction to Plato's Republic. Oxford: Oxford University Press, Chapter 3. 
change as the rules change, since it constitutes a critical attitude towards those rules. So even if present-day governmental rationalities prescribe or incorporate self-transformation (or an aestheticised lifestyle) to defuse its subversive potential, the process of self-creation proposed by Foucault cannot be reduced to this. As a critical response to the rule, it will always be 'in excess of' the rule. For such a critical response does not simply entail objecting to this or that governmental demand, but uncovering the order in which such a demand is inscribed. It is at this point that the real risk involved in the critical attitude surfaces. If it is not just a specific law that one questions, but its very epistemological underpinning, which legitimates the rules of governmental validity, then questioning the law will entail renouncing the established grounds of its validity. This is something different and far more dangerous than the simple rejection of a given law ( $c f$. Butler 2000: 222). The practice of critique, when practiced consistently, should then not only be able to keep track of changing governmentally imposed limits, but also of the politics of truth that supports it. ${ }^{22}$

\section{Difference and Repetition of the Same}

We are now much closer to understanding the true subversive core of Foucault's notion of self-transformation. Maybe the way in which these practices of the self induce effective resistance can best be explained with the aid of the Deleuzian notion of the 'repetition of the same', which Foucault discusses in one of his earlier essays, 'Theatrum philosophicum' (1970). ${ }^{23}$ However much the outcome of this process of self-stylisation depends upon heteronomously determined codes and changes accordingly, it is nevertheless essentially a repetition of the same - the repetition of the same cycle of self-creation and self-refusal of which the content might vary, but the form stays the same. In the subject's or what Foucault eventually terms the self's ${ }^{24}$ efforts to stylise his/her freedom, s/he engages in certain self-directed practical exercises technologies of the self, practical tests, self-examinations and disciplined exercises with the common goal of critically remoulding externally imposed limits (HS III, 58-65/74-82). This process of 'ethical self-creation' is then also followed by a critical relation to those self-imposed rules and ultimately by a refusal of that self-created identity. It amounts to 'an ethic for which freedom lies... in a constant attempt at self-disengagement and self-invention' (Rajchman 1985: 38), for the self is never only 'self-creative' but always and at the same time a 'being-created'. It is not easy - if at all possible - to clearly discriminate between the externally imposed and the internally initiated formative processes. ${ }^{25}$

22 Resistance effectively posed to one limit, by extension, also questions the entire order that supports it.

23 This essay is a review of two books by Gilles Deleuze: Différence et repetition (Paris: P.U.F., 1969) and Logique du sens (Paris: Editions de Minuit, 1969). Deleuze himself considers this to be a recurrent theme in Foucault: '[i]t [the inside] is not a reproduction of the Same, but a repetition of the Different. It is not the emanation of an "I", but something that places in immanence an always other or a Non-self... I do not encounter myself on the outside, I find the other in me' (Deleuze 1988: 98).

24 As Foucault shifts emphasis from subjectification to subjectivisation, he comes to prefer talking about the 'self' and it may be that, for Foucault, the latter term carries more agency than 'subject' (cf. Butler 2000: 230).

25 In her essay on Foucault's virtue, Judith Butler (2000: 230) expresses it very eloquently: ' $\ldots$ the formation of the subject is the institution of the very reflexivity that indistinguishably assumes the burden of formation. The "indistinguishability" of this line is precisely the juncture where social norms intersect with ethical demands, and where both are produced in the context of a self-making which is never fully self-inaugurated'. 
Now, what makes for the efficacy of this form of resistance is not so much that its re-formations are unpredictable. It is precisely in the predictable and doggedly persistent repetition of the practices of the self that a form of difference is unleashed that slips through the cracks of normalising power. Contrary to a difference posited in opposition to its antipode, which, as we know, is but two projections of the same axis, the form of alterity freed when the same is repeated is not susceptible to reduction or assimilation.

In his 1970 essay, Foucault refers to Andy Warhol's popular art to illustrate the way in which the repetition of the same functions. Recall Warhol's representations of Campbell's soup cans, for example: same brand, same size, same paint surface thirty-two, a hundred, even two-hundred times more of the same. Sometimes the monotony would be interrupted by the use of different colours, but then the variation would only serve to once again emphasise the repetition of the same. It is precisely the repetition of identical, recurrent soup cans, i.e. the absence of diversity, that paradoxically frees difference from suppression by identity. ' $[\mathrm{I}] \mathrm{n}$ concentrating on this boundless monotony', writes Foucault (1970: 189), 'we find the sudden illumination of multiplicity itself'. This, according to him, 'is the greatness of Warhol' (ibid.).

To be sure, Warhol has had his fifteen minutes of fame, and today this form of artistic expression has become quite commonplace. Countless artists have followed his lead and produce highly original individual pieces by using serial production techniques. Also, manufacturers of consumer products apply this principle to produce trendy objects for household use - mostly glassware like vases and decanters, but also crockery - each repetition with its own minuscule but essential idiosyncrasy. It might therefore be argued that Warhol and those who followed in his wake are not as subversive as they once were. But maybe we could come up with another, more pertinent example, illustrative of the way in which the repetition of the same is enacted as a practice of the self, which succeeds in effectively 'desubjugating' the self. I am thinking of Lars von Trier's oft-quoted 1998 film, The Idiots. Not unlike Joep van Lieshout's anarchistic enclave, the film features a group of individuals - secluded in a commune who decide to take up arms against existing social norms by pretending to be idiots and acting as mentally disabled persons. The 'idiots' confront bourgeois normality in a number of different settings. For example, in one scene, they go to a restaurant drooling over their food, lurching around the tables of unsuspecting patrons. One of the idiots clutches the hand of a solitary dinner guest, Karen, who feels empathy with the disabled and decides to accompany them. Very quickly Karen finds herself drawn into the charade, drawn to the fact that these repetitive 'rituals of retardedness' somehow succeed in liberating her from the constraints of her real life. The true test then also comes when Stoffer, the group leader, asks them to leave the security of the group, to step beyond the confines of the commune, as it were, and to introduce their role playing into their normal surroundings of work and family.

According to the Greek/Foucaultian formulation, as we have seen, ethical self-transformation aims towards the establishment of an overarching mode of being (HS II, 26-28/33-35). It is reminiscent of Aristotle's thesis that virtue is perfected by its own use, demanding from the agent a permanent actualisation that will ultimately make it habitual. Indeed, the idea that action determines a 'mode of being characteristic of the moral subject' clearly evokes Aristotle's definition of hexis as a 'state of character' or a 'relatively permanent disposition' progressively acquired through the repetition of 
specific actions. ${ }^{26}$ In this way, the modification of being that Foucault speaks about can only occur through the deliberate and reflective repetition of certain actions judged to be virtuous, which in the passage from the quantitative to the qualitative slowly transforms the ethos of the individual. It can also be understood in terms of poiesis - the Greek term for creation or production, which unlike mere action (praxis) or doing, is aimed at an end (telos). However, this does not mean that Foucault is proposing a teleological ethic as if becoming an idiot is a goal in itself. The telos consists in change, in transforming oneself and one's world - the precise form of which is not known or determinable beforehand. Instead of the telos determining the production, it is the production process itself that determines the end product. Ultimately, repeating the same 'idiotic' gestures, mannerisms, or way of being unremittingly serves as a vehicle to craft a certain self - a self ready to shrug off a subjugating subject identity and assume an identity that affords it more possibilities for thought and action - for being different.

So when the individual members of the group were asked to risk their existing subject identities by playing the idiot in their real lives, most of them failed to cross this hurdle - not ready to part with what they were. It was at this moment that the real subversive potential of the repetition of the same was revealed and it was only the "normal' Karen who was willing to go all the way. She was willing because she had to she could not return to whom she was as if nothing had happened. At first sight, Karen appeared to be the most unFoucaultian subject - blindly and uncritically embracing the values of the group; almost OVERidentifying with becoming an idiot as a goal in itself. But this is the only way - a necessary condition, if you will - in which the PRO-gressive potential of Foucault's 'infinite regress' or return of self-invention and self-refusal is unlocked. One can only abandon an identity by fully assuming it! In the process, Karen risked everything she held dear - becoming alienated from her family, being rejected by her husband, but these were the people who had the most power over her, who kept her subjected and tied to a something which she no longer wanted to be and could, for the first time, effectively resist!

What Karen ultimately managed to do is to refuse the classification of her identity into a static form that can be institutionally (and privately) dominated in favour of subjective practices that make possible a self-fashioning that is continually mobile and inventive. Although it might seem as if she discovered in the idiot-commune a way of breaking free from her subjection, in actual fact she invented 'a manner of being', that Foucault describes as 'still improbable" 27 . Now Atelier van Lieshout also attempted to be 'mobile and inventive' - literally fashioning an enclave of aesthetic anarchism. But they fail where Karen succeeds precisely because they lack sincerity. There is a certain superficiality and artificiality in Atelier van Lieshout's anarchism - a lack of necessity ... almost as if they did what they did because they could and not because they had to.

26 As The Nicomachean Ethics says: 'Moral virtue comes about as a result of habit... For the things we have to learn before we can do them, we learn by doing them, e.g. men become builders by building and lyre-players by playing the lyre; so too we become just by doing just acts' (Aristotle 1980: 28-9 [1103a 11-33]). The act does not completely disappear in its being effected, but subsists by leaving its trace in the subject's potentiality as an hexis (ibid, p. 131 [1136b 32-137a 20]; pp. 156-8 [1144b 1-1145a 11]).

27 'Friendship as a way of life', in Rabinow, P. (Ed.) 1997. Ethics: Subjectivity and Truth. New York: New Press, p. 137. 
To be fair, AVL-ville did succeed in constructing a site of resistance - but this form of resistance still belongs to the idiom of HS I, i.e. resistance understood as tactical reversal. Atelier van Lieshout struck a deal with the 'forces of domination', whereby they could maintain a measure of resistance within a network of power but without going beyond what I would call 'mere maintenance'. Maintenance merely prevents power from turning into domination but it does not actually engage with or effectively challenge those powers that tend to become oppressive. As a whole, the idiot-commune shared the same fate - serving as a vehicle for sublimating potentially seditious forces, effectively defusing them instead of allowing them to really change things. Karen, on the other hand, managed to EM-power herself - to move beyond mere agonistic relations, which are at bottom characterised by a complicity with the forces being opposed - to a positive means of resistance. She was able to act in a way that challenged and went beyond the pre-determined structuration of a field of possible actions, which is the result of the functioning of power. ${ }^{28}$

\section{Bibliography}

Aristotle. 1980. The Nicomachean Ethics, trans. William David Ross. Oxford: Oxford University Press.

Balibar, E. 2002. Politics and the Other Scene, trans. Christine Jones, James Swenson and Chris Turner. London: Verso.

Burckhardt, J. 1935. The Civilization of the Renaissance in Italy, trans. S. G. C. Middlemore. USA: Albert and Charles Boni.

Butler, J. 1990. Gender Trouble: Feminism and the Subversion of Identity. New York: Routledge.

Butler, J. 2000. 'What is Critique? An Essay on Foucault's Virtue', in Ingram, D. (Ed.) 2001. The Political: Readings in Continental Philosophy. London: Basil Blackwell, pp. 212-226.

Deleuze, G. 1988. Foucault, trans. Seán Hand. London: The Athlone Press.

Eagleton, T. 1990. The Ideology of the Aesthetic. New York: Basil Blackwell.

Foucault, M. 1970. 'Theatrum Philosophicum', in Bouchard, D. F. (Ed.) 1977. Michel Foucault. Language, Counter-Memory, Practice. Selected Essays and Interviews, trans. D. F. Bouchard and S. Simon, New York: Cornell University Press, pp. 165-196.

28 Recent South African history affords us a pantheon of 'real life' examples. The most exemplary perhaps is the Black Consciousness Movement (BCM) founded by Steve Biko. It is a grassroots anti-Apartheid activist movement that emerged in South Africa in the mid-sixties out of the political vacuum created by the decimation of the African National Congress and Pan Africanist Congress leadership following the Sharpeville Massacre in 1960. The BCM's most significant contribution to the struggle consisted in its insight that black liberation would not only come from imagining and fighting for structural political changes, which the ANC put great emphasis on, but also from psychological transformation in the minds of black people themselves. Biko argued that to take power, black people had to believe in the intrinsic value of their blackness: 'black is beautiful!'. In this way, the legacy of the BCM helped give the resistance a culture of fearlessness. Its emphasis on individual psychological pride helped ordinary people realise that they could not wait for distant leaders (who were often exiled or jailed) to liberate them. This fearlessness became the basis of a new battle in the streets - a battle waged by ordinary, often unarmed, individuals (see for example Steve Biko's I Write what I Like (Chicago, US: University of Chicago Press, 2002) and 
Foucault, M. 1977. 'Power and Strategies', in Gordon, C. (Ed.) 1980. Michel Foucault. Power/Knowledge. Selected Interviews and Other Writings 1972-1977, trans. Colin Gordon, Leo Marshall, John Mepham \& Kate Soper. Great Britain: The Harvester Press Ltd, pp.134-145.

Foucault, M. 1978. 'What is Critique?', in Lotringer, S. \& Hochroth, L. (Eds.) 1997. Michel Foucault. The Politics of Truth. New York: Semiotext(e), pp. 23-82.

Foucault, M. 1982a. 'The Subject and Power', in Dreyfus, H. L. \& Rabinow, P. 1986. Michel Foucault. Beyond Structuralism and Hermeneutics. London: The Harvester Press Limited, pp. 208-26.

Foucault, M. 1982b. 'Truth, Power, Self: An Interview', in Martin, L. H., Gutman, H., Huton, P. H. (Eds.) 1988. Technologies of the Self. Amherst: The University of Massachusetts Press, pp. 9-15.

Foucault, M. 1983c. 'On the Genealogy of Ethics: An Overview of Work in Progress', in Rabinow, P. (Ed.) 1984. The Foucault Reader. New York: Pantheon Books, pp. 340-372.

Foucault, M. 1984. 'The Ethic of Care for the Self as a Practice of Freedom. An Interview with Michel Foucault on January, 20, 1984', trans, J. D. Gauthier, in Bernauer, J. W. \& Rasmussen, D. M. (Eds.) 1988. The Final Foucault. Cambridge, MA : MIT Press, pp. 1-20.

Foucault, M. 1990a. The History of Sexuality. Volume I: Introduction, trans. Robert Hurley. London: Penguin. In French: Histoire de la sexualité, I: la valonté de savoir (1976). Paris: Galimard. Cited as HS I. (The English page reference are followed by the original French page reference).

Foucault, M. 1990b. The History of Sexuality. Volume III: The Care of the Self, trans. Robert Hurley. London: Penguin. In French: Histoire de la sexualité, III: la souci de soi (1984). Paris: Galimard. Cited as HS III.

Foucault, M. 1992. The History of Sexuality. Volume II: The Use of Pleasure, trans. Robert Hurley. London: Penguin. In French: Histoire de la sexualité, II: l'usage des plaisirs (1984). Paris: Galimard. Cited as HS II.

Greenblatt, S. 1980. Renaissance Self-fashioning: From More to Shakespeare. Chicago: University of Chicago Press.

Han, B. 2002. Foucault's Critical Project. Between the Transcendental and the Historical, trans. Edward Pile. Stanford: Stanford University Press.

Hofmeyr, A. B. 2005. 'From Usurpation to Subversion: Foucault meets Cultural Capitalism'. In: Andere Sinema, 175, 102-119 (English); 211-221 (Dutch).

Lotringer, S. \& Hochroth, L. (Eds.) 1997. Michel Foucault. The Politics of Truth. New York: Semiotext(e).

Miller, J. 1993. The Passion of Michel Foucault. New York: Anchor.

Rajchman, J. 1985. Michel Foucault. The Freedom of Philosophy. New York: Columbia University Press.

Simons, J. 1995. Foucault and the Political. London: Routledge. 
Taylor, C. 1984. 'Foucault on Freedom and Truth', in Hoy, D. C. (Ed.) 1986. Foucault. A Critical Reader. Oxford: Basil Blackwell, Ltd., pp. 69-102. 